\title{
A Study on Mechanism of Constitutional System in Israel
}

\author{
Dr. Ahmad Mohammad Al-Refaie \\ Associate Professor \\ Applied Science Private University/ Jordan \\ e-mail: dr.alrefaie@asu.edu.jo \\ Dr. Sabah Mousa Abd Alrahman Al Momani \\ Assistant Professor \\ Al-Balqa Applied University/ Jordan \\ e-mail: sabah.momani@bau.edu.jo
}

\begin{abstract}
A system means an entity that is composed of several elements interacting with each other where characteristic ofsuch system isformed due to the result of such interaction. Yet, the constitutional system is a reciprocal relationship between political phenomena that are part of the social system and related to the system of government and political organizations that are part of the social system and related to political organizations. Formation of the State of Israel went through three phases: the first of which was the creation of an organized institutions with Jewish-Zionist components, the second phase wascalling the Jews of the world to emigrate to Palestine, and the third phase was communicating with the European countries to win their support. Though the study of political systems has clearly captured attention of many scholars in the world, the Arab interest in studying constitutional systems, including the constitutional system in Israel, is still weak. It is therefore important to highlight the constitutional system in Israel and examine executive and legislative powers and the mechanism of the constitutional system of this State.
\end{abstract}

Keywords: constitutional system, flexible constitution, political parties, Knesset, Head of State.

\section{Introduction}

The constitutional system of state means the set of basic rules that define whether form of the state is simple or composite, whether system of government in the state is a monarchy or republican, and whether the constitutional system in the state adopts the absolute or restricted government, legal or authoritarian government,or individual, minority or democratic government.

The term "constitution" appeared in France in 1834, where this term was associated with the existing political system. When measured in terms of time, the term constitution is a newly established term in the world of legal thought, where it was used for the first time in connection with the revolutionary liberation movements of the United States of America after its independence, and where it developed written constitutionsregulating the form of the state, the system of government and the various authorities and the relationship between these authorities among themselves and the people, in addition to the recognition of individual and collective rights and freedoms.

Many researchers have been reluctant to discuss the system of government in the State of Israel on the pretext that it is hostile to the Arab countries. I think this is unjustifiable as academic studies do not know emotions and are not based on whims. Accordingly, the researcher has found it necessary to examine this subject to learn about the mechanism of the constitutional system in the State of Israel, as this State has conducted studies on the mechanisms of constitutional systems in the Arab countries.

The text of the Declaration of the State of Israel on May 14, 1948, stated that a constitution for the new Israeli state would be drafted by a constituent body that would be elected no later than October 1948, as provided under the text of the draft recommendation on the partition of Palestine issued by the UN General Assembly on 29/11/1947 by resolution No. 181.

Development of a special constitution for the State of Israel was met with opposition attempts and untenable justifications that will beaddressedbelow.

This research is divided into the following points: The executive and legislative powers in the State of Israel. In this topic, the executive power will be examined and then two subjects will be dealt with, namely the Head of State and the government. Then, the legisatlive power will be examined in terms of its formation and competencies of the Knesset. 
After that, mechanisms of constitutional system in Israel will be clarified through examining absence of a written constitution in Israel and the justifications behind this. Then the so-called the basic laws in Israel in lieu of a written constitution will be examined, ending with a conclusion.

\section{The executive and legislative powers in the State of Israel}

Definition of powers and adoption of the principle of separation of powers so that each power knows its lines is one of the most important principles on which the constitutional jurisprudence is based. The State of Israel, like all other States, adopts the principle of separation of powers and sets out the components and competencies of each of these powers.In this subject, the executive and legislative powers and their components will be examined.

\subsection{Executive Power}

The executive power, whether in the presidential or parliamentary systems, consists of the Head of State and government.The powers of the Head of State are broader under presidential systems, where executive power is confined to the Head of State elected by people ${ }^{1}$; a system in which theHead of State has the upper hand in balance of powers. The parliamentary system isbased on balance and cooperation between the executive and legislative powers. The most important characteristic of the parliamentary system is that it is based on the dual executive power; the head of state and the ministers, and then the balance and cooperation between the powers.

In Israel, the executive power is the main driver of political life, where the executive power is presided by the head of state. This is only formally, but in practice, the prime minister and the ministerial team are the real power holders in the state ${ }^{2}$.

\subsubsection{Head of State}

The Head of the State of Israel is elected by the Knesset by secret ballot for a period of five years, as provided under the December 1951 Law on the Presidency of the Republic. However, times of term of office are not defined. ${ }^{3}$ The Israeli Transition Law of 1949, or the so-called the Little Constitution on Presidency of Republic issued in December 1951, does not mention any condition to be met by the person elected as a president in terms of the age or citizenship, though the draft constitution developed by Dr. Cohen Committee defined some conditions. ${ }^{4}$ The head of State of Israel's position is largely a ceremonial figurehead role and he has a figurehead functions like entrusting the winner of the Prime Ministerial elections to form a new government and issuing amnesty for prisoners under the recommendation of a special committee established for this purpose. The President of the State receives the newly appointed ambassadors of foreign countries in Israel. He signs agreements with other countries, as well as appoints Judges of the Civil, Jewish, Islamic and Druze courts under the recommendation of the Government Appointments Committee. The President of Israel is elected by members of the Knesset after submitting a list of candidates. The head of state can make a public speech without interfering with political issues unless by hint.

The Head of the State of Israel cannot preside the meetings of the Council of Ministers unless the Prime Minister so requests. If the prime minister resigns and the head of state fails to find anyone who accepts to or can form a cabinet based on a parliamentary majority, the head of state cannot dissolve the Knesset, but it is the Knesset that decides to dissolve itself. ${ }^{5}$ This actually happened when Israeli Prime Minister Benjamin Netanyahu failed to rally a majority to form his own government, where Knesset enacted a law May 30, 2019 to dissolve itself, and announced conducting new elections on September 17, 2019.This is a precedent in the history of Israel, whose parliament has never dissolved itself less than two months after it was elected, where members of the Knesset approved, in the second and third readings, suggested the law to dissolve the Knesset, presented by Netanyahu's party, by 74 votes to 45 .

Further, the Knesset has the right to dismiss the head of state if it is proven that his conduct violates Israeli public policy. The Israeli Head opens the first session of Knesset, signs the treaties ratified by Knesset, signs all laws save the laws concerning his powers, receives reports of the government in connection with its sessions, delivers credentials to diplomatic representatives of the State and accepts the credentials of the diplomats accredited to the State, appoints judges of civil courts under recommendation of the Appointments Committee, appoints judges of religious courts under recommendation of the Minister of Religions, and appoints military judges in the Supreme Military Court of Appeal under recommendation of Army Chief of Staff and at request of Minister of Defense.

\footnotetext{
${ }^{1}$ Khatib, Numan, Waseetin Political Systems and Constitutional Law, Amman - Jordan, p.320.

${ }^{2}$ Wahidi, Fathi Abd Al-Nabi, System of Government in Israel, Haia Khairia Press, Gaza, 1997, p.43.

${ }^{3}$ Bunnear, Republic of Israel, New York, 1950, p.120.

${ }^{4}$ Bunnear, ibid, p. 125 .

${ }^{5}$ Wahidi, ibid, p.47.
} 
Further, the president performs many honorary functions and tasks like entrusting a member of the Knesset to form the government, and the Prime Minister renders registration of his government to the head of state.

The head of state can resign from his post by submitting a written resignation letter to the Speaker of the Knesset, and resignation is effective and the post becomes vacant forty-eight hours after receipt by the Speaker of Knesset the resignation letter.

\subsubsection{Government}

While the head of state in Israel represents the first component of the executive power, the government is the second component; in implementation of the provisions of the general rules of the parliamentary system adopted by the Israeli political system, which is based on the dual executive apparatus represented by the head of state and the prime minister, which is adopted by the Jordanian constitutional legislator ${ }^{6}$. The State of Israel has had three basic laws of government; the Basic Laws of 1968, 1992, 2001, and 2001. We will talk about the provisions contained inthe Constitution of 2001.

The Government of Israel (Council of Ministers) is formed to administer internal and external affairs and is authorized to take steps in any area that is not legally subject to the power of another authority.

The Government of Israel is the supreme executive power, which can only function if it has the confidence of the legislative power.The authorities of the executive power are defined by the Administration Law of the Provisional Council of State, which was adopted after the establishment of the State had been declared. Formation of the Israeli government is governed by the Basic Law of the Government, issued in 2001, which indicates that the government in Israel is an executive power and is based in Jerusalem. This law also cancels the election of the Prime Minister directly, rather he is appointed and then he gains confidence from the Knesset, and it defines the responsibility of the Prime Minister before the law and the responsibilities of each Minister before the head of state. Traditionally, the head of State entrusts the leader of the party that achieves the largest number of seats in the Knesset to form a government, provided that the Prime Minister-designate is a member of the Knesset.

The ministers can be non-members of the Knesset and the government is formed after consultations by the Prime Minister-designate with the leaders of other parties represented in Knesset and gives the President-designate a legal period of 28 days, renewable for 14 days. If the prime minister-designate does not succeed in forming a government, then the head of state entrusts another person to do so. If the other person is unable to form a government, this means that the parties have failed to designate a candidate who has the confidence of the Knesset.

In order for the government to gain the confidence of the Knesset, 61 votes must be obtained, as well as a vote of no confidence in it. The Knesset therefore ratifies dissolving itself and calls for early general elections ${ }^{7}$. However, if the government is formed, the prime minister-designate must prepare a list of names of ministers and submit it to the Knesset for ratification. After ratification, the ministers remain responsible to the prime minister for performance of their duties.

The term of office of each government lasts for four years, as is the Knesset. This term of office can be shortened in the event of the death or resignation of the Prime Minister or a vote of no-confidence in such government in the Knesset. As for the powers and functions of the government, it is required to act on behalf of the state in accordance with the law, where it adopts the principle of separation of powers, where each ministry has competencies determined by the law. At large, the function of the government is to define and implement foreign affairs, internal security and economy policies. Once the government is appointed, the Prime Minister must deliver the following declaration of loyalty " I, (name), am committed to loyalty to the State of Israel and its laws and to fulfilling my duties as Prime Minister with sincerity and implementation of the Knesset resolutions", and each minister is required to deliver the ministers' oath of loyalty.

\subsection{Legislative Power}

In all States, the legislative power means the body responsible for enacting laws, monitoring government performance, and holding the government accountable for its actions. This body is represented in a parliament elected by the people and this is called parliamentary democracy. Upon the establishment of the State of Israel, this task was entrusted to the Council of State, which enacted, on 8/11/1948, the Law on Election of the Constituent Assembly. On 14 February 1949, the Transitional Law was promulgated and ratified by the Constituent Assembly. This law remained known as the new Constitution and, under Article 1 of the Little Constitution, Israel's legislature is called the Knesset. Affairs of Knesset (parliament) are organized under two laws, namely the Knesset Law of 1955 and the Basic Law of $1958^{8}$. Formation and competencies of Knesset will be discussed below:

\footnotetext{
${ }^{6}$ Debis, Hesham, Waseet in Constitutional System, Amman, Dar Thqafa, 2014, p.78.

${ }^{7}$ Wahidi, ibid, p.53.

${ }^{8}$ Wahidi, ibid, P. $67 \& 68$.

128
} 


\subsubsection{Formation of Knesset}

The Knesset is the parliament of the State and is based in Jerusalem. It is composed of 120 members elected in general, national, direct, equal, secret and proportional elections in accordance with the Knesset Law, and the number of 120 members of the Knesset is taken after the Council which was under the reign of one of the kings of Israel and named (Ezra), which was named Hagola Knesset and which means the Great Council.

The term of the Knesset is 4 years starting from the date of its first meeting held after the elections. The Knesset includes 15 standing committees with certain competencies for each. These committees are distributed among all members of Knesset. Members of these committees are elected by an organizational committee composed of representatives of political parties in Knesset in a manner that ensures representation of all parties by their parliamentary power. There is a constitutional custom that ministers may not take part in these committees.

Every Israeli citizen over the age of 18 has the right to vote in the Knesset elections, unless there is a legal bar. As for the conditions of candidacy, there are stipulated in the Knesset Basic Law, which provides that every Israeli citizen over the age of twenty-one on the day of submission of the list of candidates may stand for election to the Knesset, unless the court extracts this right or if he is sentenced by a final decision for imprisonment for a period exceeding three months and unlessa period a 7 year-period from the end of his sentence to the date of submitting the nomination lapses. ${ }^{9}$

A Knesset member must be an Israeli national. For Palestinian Arabs, a member must have been a permanent resident since 1948 and be at least 21 years old and not convicted in criminal cases, and it is required that he is a member in a political party. The head of state, judges, clerics, police officers, the army and senior officials are deprived of the right to stand for election. The law does not define Senior officials, but it could be deducted from other laws. Elections in Israel are based on a closed-list system, where each party submits a list of its candidates according to importance, and this system is rigid and inflexible. The whole country is considered as a single electoral district and voting is conducted for the party list as a whole and not for individuals. The principle of proportional representation system is adopted so as to divide what has achieved by each list by 120 , the number of members of the Knesset and this was prevalent in the Persian era, where the population of the Jewish Council was 120 members. Numbers less than $1.5 \%$ are collected and then distributed to the parties according to the percentage of their seats in parliament. The Central Election Commission, chaired by a judge of the Supreme Court, conducts the elections. ${ }^{10}$

\subsubsection{Competencies of Knesset}

The legislative power in Israel, represented by the Knesset, has wide powers, where the Knesset holds its first session on Monday of the second week after the election results are published at 4:00 pm. The head of state opens the session, and if he is absent, the session is chaired by the most senior member of Knesset. The Knesset exercises the following functions:

1. Legislative Functions: enactment of laws- this task goes through two phases; the first of which is the voting phase, which permits submission of such proposals by the government a member or more of Knesset, where most of proposals, in practice, are submitted by the government that constitutes the winning majority in the Knesset. The second phase is discussion and ratification of the draft law. The draft law is discussed and voted on through three readings:

a. Reading 1: where the body submitting the draft law explains its view on the draft law and its importance.

b. Reading 2: it is made by the specialized committee in Knesset, where the draft law is examined and amended.

c. Reading 3: the draft law is presented as submitted by the specialized committee and it is voted on. If it is approved, the prime minister and ministers sign and ratify it and then it is submitted to the head of state. Other functions of Knesset include approval and ratification of treaties and submission of them to the head of state.

2. Financial Functions: the Knesset ratifies the State Budget Law, and develops and amends the taxes laws. In addition to these financial competencies, Knesset discusses the State's report on the financial conditions and determines salaries of the prime minister and ministers.

3.Political Functions: these functions include monitoring the government performance and accountability, and Knesset oversees the government through questions, interrogations, parliamentary investigation and non-confidence. Knesset also elects the head of state, approves declaration of war, and appoints judges of supreme court, and it may decide to dissolve itself.

\footnotetext{
${ }^{9}$ Article 6 of the Basic Law of Knesset, Encyclopedia of Terminology, 1837, Knesset.
} 


\section{Mechanism of Constitutional System in Israel}

Undoubtedly, each state has three elements: the people, territory and political power, and in each political society,there must be a constitution that includes a set of rules that form the general framework of the political system. This framework explains the three powers of the state and rights and freedoms. As to the mechanism of the constitutional system in Israel,the Declaration of the State of Israel, issued on 14 May 1948, states that the Constitution of the State shall be developed by a Constituent Assembly, to be elected no later than October 10, 1948.

There are three trends concerning development of constitution: Trend 1: supports the need for development of a constitution of the state with the aim of organizing the powers and protecting rights and freedoms in the state. Further, the Decision of Partition of 1947 asserted importance of development of a constitution of the state.

Tend 2: argues that there is not urgent need to develop a constitution, since minority of Jews of the world have returned. It also argues that assembling the Jews of the world is more important than development of a constitution, and that development of the Constitution may cause divisions, and that it is not permissible to speed up development of the Constitution since thestate borders that must be clarified by the Constitution is unclear.

Trend 3: it is an intermediate trend and it argues that organization of the state and its powers is achieved through special laws to be collected in the future in a constitution. ${ }^{11}$ In fact, Israel has been facing a constitutional crisis to date. It does not have a written constitution since the religious parties only believes in one constitution, namely Torah. It is a religious state that must comply with teachings of Judaism. Other religious parties confronting the religious parties argue that there is not need to mention religion of the state in the constitution, Torah must not therefore be a religion and there must not be a constitution. ${ }^{12}$

As the views on the necessity of development the constitution were divided, the views on the nature of the state itself were divided into two parts: one calls for building the Israeli state based on religious thought using the teachings of Jewish law; and the other calls for secularism and state-building on a capitalist or socialist basis.

According to these conflicting ideas, many suggestions have been submitted by several entities. Members of the Knesset, led by Harare, called for development of a constitution, provided that it is discussed on a chapter-by-chapter basis. Another trend argues that a period of time must be determined to review the achievements made in connection with the constitution. The religious body has suggested to enact the so-called basic laws that will be developed later. In practice, Israel has so far suffered from a constitutional crisis. Failure of Israel to develop a written constitution is attributed to the religious and ideological differences between members of Israeli society, where part of them has greatly confronted the religious trend, which prevented an effect of the religious creed in the Israeli laws. Examples of this include contents of the Jewish personal status laws, such as polygamy, which is prohibited by secular laws, noting that the Jewish tradition makes it permissible. Further, divorce has been abolished, rather a person who divorced his wife without her consent is subject to punishment. There is also the Women's Equality Act, which is contrary to Jewish religious traditions ${ }^{13}$ The other reason behind the Israeli constitutional crisis is that Zionism does not adopt a certain basic principle and does not conceive of political power, it still lives in its political system on the Anglo-Saxon tradition and therefore it could be said that Israel is a parliamentary republic from a constitutional perspective. ${ }^{14}$

Hence, the constitutional crisis in Israel should not be considered an indication of its lack of strength, since the Israeli constitutional system is more coherent and stronger than some other systems due to the organic cohesion linking the governing class with the governed classes. ${ }^{15}$

Regarding the organization of political authorities in Israel, it should be emphasized that every political society must have a constitutional framework.

\section{Conclusion}

The constitutional document often lacks rules relating only to the regulation of the exercise of power, rather in addition to these rules, there are provisions in connection with rights and freedoms of citizens, and obligations of the state towards these citizens. These provisions are often either provided in the preamble of constitutions or contained in a chapter of constitutions.

\footnotetext{
${ }^{11}$ Argued by David Pangorion, the first Prime Minister of Israel

${ }^{12}$ Dr. Abd Al-Hamid Metwali, System of Government in Israel, Institute of Studies, Cairo, 1964, p.180.

${ }^{13}$ Yale Ayal, Internal Structure of Power in Israel, p.245.

${ }^{14}$ Morris Prinson, Political and Social Life in Israel, translated by Fares Gharib, Dar Al-Kholoud, Beirut, 1979, p. 26.

${ }^{15}$ Said Elwa, Management of Public Projects in the Israeli Economy, PLO Research Center, Beirut, 1981, p. 47. 
If the state constitution is in principle a power on which rulers rely and is exercised under certain rules, the constitutional rules, then such power is not exercised for exercise itself, rather rules have options, philosophy and ideological reference that inspire their exercise of power and determine dimensions and sense or total of such exercise. Israel, which claims democracy, is in fact living on the misery of others.

The Arab-Israeli citizens do not have the lowest level of rights and freedoms, as they are deprived of many senior positions. Israel does not want to develop a written constitution that contains rights and freedoms, the state border and its public finance sources. Due to absence of a constitution, there is no constitutional judiciary that controls constitutionality of laws, allowing Knesset to enact any laws it wishes without being held accountable to anybody. Israel has adopted the principle of separation of powers and parliamentary government. This is shown through the principle of dual executive power, which is composed of the head of state and Council of Ministers. The head of state is elected in a manner that each party elects a candidate and presents him to Knesset. Ten and more Knesset members are entitled submit a nomination application for a person with his consent. A week before election, the Knesset Speake announced names of candidates, and a secret ballot is conduced in this respect. The winner must receive 61 votes or more of the 120-member Knesset. The head of state has some honorary competencies. The government is formed through entrustment of the party leader which holds the largest number of Knesset seats by the head of state to form the government. This has been discussed in detail. We argue that Israel does not have a written constitution. Some people support existence of the constitution, while other people deny its existence.

\section{Recommendations}

- The researchers believe that there should be a written and clear constitution since this would guarantee greater rights and freedoms and emphasize the principle of legality.

- There should be a quota for the Arabs in the Knesset to have appropriate representation.

- There should be consensus among Arab members of Knesset to be able to tip the majority.

Dr. Ahmad Mohammad Refaiewould like to extend his heartfelt thanks to the Applied Science University for support of this research.

\section{References}

Argued by David Pangorion, the first Prime Minister of Israel.

Article 6 of the Basic Law of Knesset, Encyclopedia of Terminology, 1837, Knesset.

Badawi, Tharwat, Constitutional Law and the Development of Constitutional Systems in Egypt, Dar Al-Nahda, Cairo, 1971.

Bunnear, Republic of Israel, New York, 1950,

Debis, Hesham, Waseet in Constitutional System, Amman, Dar Thqafa,

Dr. Abd Al-Hamid Metwali, System of Government in Israel, Institute of Studies, Cairo, 1964

Khatib, Numan, Waseet in Political Systems and Constitutional Law, Amman - Jordan,

Morris Prinson, Political and Social Life in Israel, translated by Fares Gharib, Dar Al-Kholoud, Beirut, 1979

Said Elwa, Management of Public Projects in the Israeli Economy, PLO Research Center, Beirut, 1981

Wahidi, Fathi Abd Al-Nabi, System of Government in Israel, Haia Khairia Press, Gaza, 1997

Yale Ayal, Internal Structure of Power in Israel 